\title{
Eastern European Exilic Trajectories in Post-1989 Life Writing
}

\author{
Ioana Luca
}

National Taiwan Normal University

\section{ABSTRACT IN ENGLISH}

My article offers a comparative analysis of autobiographical works by Susan Suleiman, Andrei Codrescu and Kapka Kassabova with a three-pronged interest. First, I aim to further the discussion about exilic identities emerging from Eastern Europe; second, I show the "shifting national, global imaginaries" that post-1989 Eastern European exiles' life writing registers; and third, I analyze how Suleiman, Codrescu and Kassabova negotiate affective attachments with their "native" Eastern European countries in the aftermath of the Cold War. I consider their life writing important as it captures the overlappings and complicities between apparently opposite regimes-Nazism, Communism and/or post-communism-and in so doing they animate a historical imaginary of the recent past in Eastern Europe. Their trajectories of exile and return become a lens for the larger variations of exilic subjectivity in post-Cold War Eastern Europe.

\section{ABSTRACT IN ROMANIAN}

Articolul oferă o analiză comparativă a autobiografiilor scrise de Susan Suleiman, Andrei Codrescu şi Kapka Kassabova şi urmăreşte trei direcţii principale. Discut identităţile formate ca urmare a exilului din Europa de Est şi continui dezbaterile critice pe această temă; analizez „imaginariile naţionale şi globale în continuă schimbare" pe care scriitura autobiografică post-1989 le prezintă; explorez modalitaţile în care Suleiman, Codrescu şi Kassabova negociază legăturile afective cu ţările natale după căderea comunismului. Autobiografiile investigate se disting prin prezentarea suprapunerile şi asemănările dintre regimuri aparent opuse-Nazism, Comunism şi/sau post-comunism-şi prin felul în care dau viaţă imaginarului istoric al trecutului recent în Europa de 
Est. Consider traiectoriile exilului şi ale întoarcerilor în ţara natală discutate în prezentul articol emblematice pentru varietatea identităţii exilice din Europa de Est în perioada postcomunistă.

I chose to see emigration and globe-trotting as an escape, not as a loss. Nowhere to call home? No problem, the world is my oyster. Where are you from? They ask. Does it matter? I answer. But it does. (Kassabova, 2009, pp. 15-16)

Exile from behind the Iron Curtain was caused by political and economic reasons, loss of creative and personal freedoms (Segel 2008, p. 363), inherited trauma of Nazi Germany or Stalinist Communism or both (Rădulescu 2002, p. 3), it meant a desire to escape want, a search for freedom and dignity. John Neubauer's definition offers a very comprehensive view, touching upon the constitutive elements of departure from East and Central Europe:

exile usually meant a self-motivated, or, occasionally, forced departure from the home country or habitual place of residence, because of a threat to the person's freedom or dignified survival, such as imminent arrest, sentence, forced labor, or even extermination. The departure was for an unforeseeable time irreversible. (Neubauer 2009, p. 8)

"Threat", "dignified survival", "arrest", "sentence", "forced labour" clearly ground Neubauer's explanation in the specific realities of Nazism and Communism in the region. Such functional characterizations of the large-scale migration from Eastern Europe in the second half of the 20th century offer the larger background against which individual interpretative frames are to be understood.

Starting from the assumption that autobiographical expressions of sociopolitical formations offer critical insight into the manifold meanings of lived history and take us to spheres of experience before theoretical configurations (or even against them) my paper furthers the discussion about exilic identities emerging from the former Eastern Europe ${ }^{1}$ in order to answer the following questions: How are identities marked by

${ }^{1}$ I use the "Eastern Europe" in the Cold War acceptance of the term, namely the European countries which came under the Soviet influence. For studies on the "imaginative geography" of Eastern Europe see Wolff, Todorova, Goldsworthy, Hammond (2005). 
the successive experience of Nazism, Communism and post-communism presented in post-1989 exiles' life writing? How do exiles negotiate affective attachments to their "native" Eastern European countries in the aftermath of the Cold War? How is Eastern Europe envisioned in their writings? What "shifting national, global imaginaries" (Smith 2011, p. 565) do their post-1989 life writing register?

To answer these questions I offer a comparative analysis of departures from and returns to Eastern Europe with reference to the life writing of Susan Suleiman, Andrei Codrescu and Kapka Kassabova. ${ }^{2}$ I consider their life writing important as it captures the overlappings and complicities between apparently opposite regimes and in so doing they animate a historical imaginary (Smith p. 565) of the recent past in Eastern Europe. The home they leave and return to (physically and in writing) is an emotional space but their affective connections are clearly marked by the ideological, historical periods their lives straddle: Nazism, Communism and/or post-communism. I follow how specific historical and cultural contexts inform and recode their identities leading to a variety of exilic responses which complement better-known ones by Julia Kristeva, Eva Hoffman or Milan Kundera for instance. ${ }^{3}$ I take their trajectories of exile and return as a lens for the larger variations of exilic subjectivity in the post-Cold War Eastern Europe. My article highlights

\footnotetext{
${ }^{2}$ My paper focuses on their autobiographies and memoirs proper but I chose the more embracing term "life writing" as defined by Smith and Watson in Reading Autobiography (2010, pp. 4-18) given the significance the autobiographical element acquires in the work of the above mentioned authors.

${ }^{3}$ The well-known Eastern European exiles, Julia Kristeva (Bulgaria) and Eva Hoffman (Poland) tend to embrace a celebratory interpretation. Kristeva posits that foreigners should be happy because of their liberating, mobile migration and their singular authentic experience of alienation. Her view of estrangement ignores or minimizes the hardships the foreigners endure; it also levels out the differences and specificities of estrangement that various historical moments and geographical places have led to, see "Y at-il" and Strangers to Ourselves (Kristeva 1991, 2000). Eva Hoffman examines the implications of exile in the aftermath of the Cold War and she also tends to celebrate exile, adhering to Nabokov's opinion that "loss is a magical preservative". Similarly to Kristeva and numerous postcolonial thinkers, Hoffman counters essentialized notions of home, rootedness, and static identities to advocate the possibilities created by mobility and difference. Differently from Kristeva, she does anchor her analysis in the post-Cold War reality but though she embraces a "nomadic" understanding of exile, the subversive nature of the nomad-and nomadism at large-inherent in Deleuze's understanding, becomes elusive and almost lost in Hoffman's post-Cold War "new nomad", see "The New Nomads" (Hoffman 1999). Milan Kundera's 1999 novel Ignorance, on the other hand, offers a far more complex and nuanced understanding of exile and return to Eastern Europe in his emblematic characters of Czech exiles Josef and Irene.
} 
the mutual dependence between historical time and geographical space with reference to the former Cold War "Other", and it also points to the ways Eastern European exiles' life narratives contribute to what the present cluster proposes as post-1989 life writing from the Eastern bloc-a field whose defining parameters, boundaries and territory is yet to be mapped.

\section{SUSAN SULEIMAN'S HUNGARIAN ITINERARIES}

The present autobiographical corpus, emblematic but by no means exhaustive, takes as a starting point Susan Suleiman's Budapest Diary: In Search of the Motherbook (1996) the story of the author's returns in the mid-1980s and early 1990s to her native Hungary. The professor of French and Comparative literature at Harvard tells the "the story of a woman's return, after many years of forgetfulness, to a city she once called home" (p. 14), a life story which straddles Nazism, Communism and post-communism. ${ }^{4}$ These political and historical changes clearly inscribe her life into a "much longer story" (p. 14) that of the Eastern European Jews, who survived the Holocaust, and experienced the "Soviet liberation" only to flee elsewhere.

Suleiman comes in 1984 for a "brief vacation" to Budapest where she takes the "most impersonal, most ritualized way" to introduce her two sons to the city, a bilingual tour bus, and in general she feels "detached, like a tourist" (p. 28). She does not "remember anything", her childhood street looks "alien", the "past unreachable" (pp. 25, 26), she cannot connect with the person she had been or with the meaning her native home once had for her (p. 28). The attempt to revisit the life of her past highlights her sense of "estrangement", un-belonging, while Budapest's rich historical and touristic legacy stands for her "native pride" she wants to display to her children rather than an affective and emotional bond the visit recreates. The narrative of her first return includes numerous flashbacks which tell the story of her childhood, through the perspective of a six year old girl. It is a story of "luck" when the concierge did not reveal their Jewish roots and let them go, or when not knowing what "maiden name" (p. 35) meant saved the entire family, a life hiding under "false papers" (p. 34) during the final years of the war, and a "real life drama" (p. 5) of escape

\footnotetext{
${ }^{4}$ Suleiman's academic publications range from Authoritarian Fictions: The Ideological Novel as a Literary Genre (1983) to French Global: A New Approach to Literary History (2010) having covered feminist and psychoanalytical reinterpretations of classical literature, avant-garde literature and art, memory and its ethical implications in the context of the Holocaust, and, more recently, global repositionings of French civilization.
} 
from communist Hungary, crossing cornfields and barbed wire, illegally boarding trains to Vienna.

The flashbacks-in italics—adequately rendering fragments of her memory are woven with the mature critic's reflections on them, the story of the initial visit to Budapest and the consequent thoughts this triggered. However, there is "no Time Recaptured" (p. 25) in 1984, no feelings of longing for or belonging to her place of origin.

The second visit, a longer one, is enabled by the Fall of the Berlin Wall when "uncrossable" boundaries and "absolute" differences "between past and present, Hungarian and English, Budapest and Boston" became "blurred" (pp. 12-13) and the letter of invitation from Collegium Budapest, carried "a call from another world" she could not refuse (emphasis mine p. 13). The second and larger section of her memoir offers the story of her 6 months stay when recording her experience after the "Change" in Budapest became the "most compelling" project (p. 13). Fragments of childhood memory give way to a diary proper- her "pruned and edited" 1993 diary with "most of the names changed" (p. 14) —where events and thoughts are recorded on a regular basis offering the reader the atmosphere of Budapest and Hungarian academic life in the early 1990s. Budapest is still seen "through a foreigner's eyes" but now she is no longer a tourist, she is the returned academic looking for roots, tracking the exact family history, the mourning daughter in search of her mother's birth certificate.

The socio-political realities of the moment, the Hungarian nationalism and anti-Semitism she relentlessly records, can inscribe Suleiman's story of return to post-Shoah Eastern Europe as a story of "un-belonging". Exploring the Jewish Hungarian identity (with its inherent contradictions and paradoxes) will become one of her long-term academic interests but in 1993 it is her professional identity—the established Harvard academic (the phrase "professor at Harvard" is a recurrent one) — which plays an important part in the way she inscribes her belonging and relates herself to Hungary past and present. Suleiman feels "familiar in the [Hungarian] university", and she can finally think of Budapest as "another home" (emphasis mine p. 171). The present professional belonging turns her from a tourist and a foreigner into "something in-between...not quite the real thing [a Hungarian], though sometimes close to passing for it" (p. 84) and leads to embracing of her past, reconnecting with her childhood home. If the departure from and early 1990s returns to Hungary are conditioned by historical changes, her belonging is predicated on

${ }^{5}$ For an interpretation of Suleiman as "not fitting in" see Polouektova (2009, p. 446). 
both personal and professional vectors. ${ }^{6}$ Her newly established professional ties with Hungary, and the acknowledged turn her career took show how her belonging comes via "affiliation" rather than "filiation" to use Said's terms. ${ }^{7}$ Her Hungarian itineraries led her to explore the intricate processes of the redefinitions of Jewish identity in Eastern Europe from the mid-19th century to the present by transposing them in scholarly books. Both her Jewishness and Hungarian-ness (with the tensions the co-existence between the two imply) are displaced, de- and reterritorialized in her academic work on literature or film in relation to topics such as the 1.5 generation, Eastern European exile, the ethics of memory. ${ }^{8}$ In so doing Suleiman the academic has made out of her life a text that she rewrites in most of her critical studies. ${ }^{9}$

Her exilic identity is not one of transcendence and happy foreigners but a gradual coming to terms with the past, with loss and pain. Even after "Acacia street"-her childhood home-does become "part of her life" (p. 229), another home, her life feels to her like a "bombed out house, with only the walls still standing" (p. 225). Such a confession in the final pages of the book undermines the detective turn the memoir takes when she is in search of her mother's birth certificate and problematizes the multiple homes she mentions as they are predicated on painful losses "abandoned friendships, lost loves, walls built around ...solitude" (p. 225).

The way Budapest is portrayed points to the ways she relates affectively with her native city. The city of her birth, from which her family had to flee in the $1950 \mathrm{~s}$, a beautiful capital with which she did not reconnect in the 80s, is in 1993 "an interloping passion", defined in relation to Paris, her "adopted city" that functions as home (p. 126). She is exalted now by the beauty of the city (p. 63) but neither her native city nor her childhood home are idealized or totally recaptured. Acacia street is "a point"

\footnotetext{
${ }^{6}$ For Suleiman's discussion of the personal "trigger" of the visit (the death of her mother) see Armstrong (1998, p. 166).

7 "Filliation" according to Said means the ties that an individual has with the places and people of his/her natal culture, while "affiliation" entails the links that are established with all kinds of institutions and groups. "The filiative scheme", writes Said, "belongs to the realm of nature and 'life', whereas affiliation belongs exclusively to culture and society" (Said 1991, p. 20).

${ }^{8}$ The "1.5 generation" refers to those persons who, like Suleiman herself, were children during the Holocaust, and, as such, too young to fully understand what was happening during and after the Second World War.

${ }^{9}$ The books she wrote or co-edited after 1993 are clearly inflected by her stay in Budapest. More recent contributions ("Writing on") prove the existential long term effect the return to Budapest had on her identity. For a discussion of Suleiman's diary in connection with Risking Who One Is and Crisis of Memory see Luca "Leaves".
} 
along the "traveller's" way while her "passionate fling" with Budapest is relativized in multiple ways. First, the very terms she uses- "interloping", "fling",- - are telling and in contrast with her love for Paris. Second, the keen eye of the Western academic captures the street life, the aggressiveness and rudeness of people's behavior, and the contradictory spirit of the city caught in the pangs of post-communist transition. Third, the perspective of her son is counterpointed to her own, he notices much more than her "how run down and poor things look", how "dirty" turnof-the-century buildings on one of the main boulevards are (p. 131). The depiction of Budapest in Suleiman speaks thus of her own personal and professional ties with the city, as well as of the historical changes of 1989 which enabled a bridge and dialogue between past and present, US-Hungary for the exiled academic.

Eclectic and hybrid in form-diary, autobiographical reflection, flashbacks, vignettes-Budapest Diary maps Suleiman's Hungarian itineraries and points to their importance in her later work. The book records the author's reconnection with her place of birth, and the rediscovery of the native country in the aftermath of the Cold War. It speaks of Suleiman the academic and her Eastern European belonging and in so doing it explains and translates glimpses of Hungary during Nazism, Communism and post-communism. In the light of Alfred Hornung's (2013) return paradigms (outlined in the present cluster), Suleiman's memoir adds the academic's encounter with Eastern European history in the aftermath of the Cold War. ${ }^{10}$

The invitation to Collegium Budapest, enabled by the fall of the Berlin Wall, triggered her life writing project and her belonging, however problematic, to Hungary. Her identity and life writing project, as well as the depiction of Budapest in her work, are negotiated along personal, professional and historical routes which, of course, had as a starting point her roots. By taking up life writing and continuing to spin the story of her life in her academic work, Suleiman clearly emphasizes the linkages between private and professional experiences, national and global historical changes with reference to Eastern Europe. She gives prominence to the Hungarian context in scholarly work and enacts one of the post-1989 life writing trajectories, namely the academic autobiography. ${ }^{11}$ She becomes one of the first US academics of Eastern European Jewish descent whose

\footnotetext{
${ }^{10}$ In the analysis of Eastern European exiles' autobiographies in Canada, Hornung highlights the significance of Eastern European personal or collective history in the formation of the transcultural self and identifies four types of encounters with history in the return visits their autobiographies register: family reunion, political motivation, family tourism and the dead.

${ }^{11}$ For academic autobiography see Davis, (2009a, b) and Franklin (2009).
} 
life and scholarship will increasingly take place between routes and roots and whose returns will prompt further autobiographical (related) studies on Eastern Europe. ${ }^{12}$

\section{ANDREI CODRESCU'S ROMANIAN LITERARY BELONGINGS}

Suleiman's existential quest for roots with the consequent academic belonging could be counterpointed with Andrei Codrescu's trajectory, a much more light- heartedly and humorously presented one. He shares the Jewish ancestry with Suleiman but he presents his story of exile from communist Romania to the US as a happy American success story. A professor of English, Codrescu has also enjoyed the career of an extremely popular radio-commentator, prolific writer, editor, and award winning film maker. ${ }^{13}$ By making reference to The Disappearance of the Outside (1990), and The Hole in the Flag: A Romanian Exile's Story of Return and Revolution (1991), I show the changing significance of exilic identity in the Romanian communist and post-communist context, the way Romania is portrayed at different historical moments and how his autobiographical project becomes an open ended one.

Codrescu lived under the stifling atmosphere of the communist regime of the 1950s and 1960s in Romania but exile for him meant more than a (re)turn to normality, overcoming the communist handicap, acquiring one's own inner balance (Spiridon 1998, p. 225); exile for him had mythical and almost mystical connotations. It was a "place" (1990, p. 40) with a pantheon in which he places himself along the great tradition of both Romanian exiles (Constantin Brâncuşi, Tristan Tzara, Eugene Ionesco, Mircea Eliade, and Emil Cioran) and other Eastern European ones (Milan Kundera, Czeslaw Milosz, Witold Gombrowicz, or Isaac Singer) and which draws him, like a magnet, out of his country.

The tragic valences and associations that the communist context lends to his leaving the country, namely the old-style banishment- "I would lose my Romanian citizenship, and never again be allowed to live in Sibiu" (1990, p. 38) - are rendered to show the appealing concept of exile which becomes even more attractive in its difficulty, rather than an existential anguish. Codrescu shares in this sense the exhilaration and exaltation

\footnotetext{
${ }^{12}$ See for instance Hirsch Family Frames (1997), Ghosts of Home (2010), The Generation of Postmemory (2012) and Miller What They Saved (2011) as well as their co-edited collection Rites of Return (2011).

${ }^{13}$ He is well known to the American public from NPR's show All Things Considered, and through his prolific work which includes more than 30 volumes of poetry, essays, novels, travelogues and autobiographies.
} 
experienced by other literary exiles from the communist bloc. Going into exile from a totalitarian country to a democratic one meant "going home", because the exiled writer "gets closer to the seat of the ideal which inspired him all along" (Brodsky 1995, p. 24). Codrescu continues to view his exile in celebratory terms by embracing the American ethos and describes his arrival to the US as a "fortunate juncture" (1990, p. 45) because "the advantages of being a literal exile in a country obsessed by the myth of it are innumerable" (1990, p. 42).

The implications of being Jewish and the role his origin played for his exilic identity differ from Suleiman. Although his mother's whole family died in Auschwitz, awareness of and grappling with such traumas are vague and rare in his writings. Neither did he endure the life-long drama that Brodsky or other Eastern European intellectuals and writers underwent. ${ }^{14}$ On the contrary, his Jewish identity was the enabling force which facilitated the departure, as he emigrated as part of what was later revealed as a secret bargain between Israel and Romania: Romanian citizens of Jewish background were allowed to leave the country against barter or cash exchange with Israel. ${ }^{15}$ For Codrescu coming to terms with latent exclusions he perceived as a Jew in Romania meant actually coming to terms with one more system of implicit exclusion and oppression among many others to which the communist regime subjected individuals.

Although Codrescu does belong to and markedly situates himself in the long tradition of Romanian exiles (both Jewish and non-Jewish), his understanding of exile as a means of artistic fulfilment and cultural affiliation takes precedence both over the socio-political communist context and, interestingly enough, over his own Jewish identity. Codrescu's artistic and cultural affiliations transcend any boundaries that might divide him from an Eliade or Cioran with whom he almost desperately wants to share his exilic positioning. Codrescu almost never associates such names with their early political affiliation with the Iron Guard-a common practice and embattled cause with many other (émigré) Jewish Romanians (e.g., Mihail Sebastian, Norman Manea). Even in the rare instances when he does so, their intellectual and artistic heritage becomes more important than their early politics. ${ }^{16}$

\footnotetext{
${ }^{14}$ For a depiction of Joseph Brodsky's early childhood in the overtly anti-Semitic post-war Soviet Union, see Brodsky (1986, pp. 7-8); see also Boym (2001, p. 305) with reference to a letter with anti-Semitic threats that Brodsky received from Moscow, a year before his death.

${ }^{15}$ For the barter with Israel, see Codrescu "How", Talbot, "Romania" and Ioanid, The Ransom (2005).

${ }^{16}$ While other Romanian writers of Jewish origin attacked and criticized in their writings the anti-Semitism of Mircea Eliade or Emil Cioran and their affiliation with the Iron Guard [see Mihail Sebastian (2006), Norman Manea (1991)], Codrescu invokes them in relation
} 
His autobiographical project mirrors and counterpoints the longing for exile with his longing for return as he inscribes it with clear artistic connotations. In The Hole in the Flag-his memoir cum travelogue occasioned by the Revolution of 1989-Codrescu imagines himself pulling up to the Capşa Café in a convertible white Cadillac, with a poet's laurel crown "at a jaunty angle on my long tresses" (1991, p. 16). The reference to the famous Bucharest Capşa Café- "the meeting place of venerable writers for over a century"-places him again within a literary tradition, the Romanian one. Imaginary homecomings turn his native country into a fantasy world, a mythical one, viewed from childhood memories which he presents in the US with images drawn from the folkloric and poetic tradition of national self-imagining: "I told everyone, we all will go to Romania to eat plums from apple trees, pears from poplars, honey from streams. Romania was more fairy tale than real place to them" (1991, p. 54). Such images come in stark contrast with the journalistic depiction he renders about the immediate aftermath of the Revolution in the same book.

In recording the significance his exilic identity acquires upon his return, Codrescu records and translates the paradoxes of the post-1989 period in Romania. If, on a late December evening in his hometown Sibiu, he felt more than ever before "an alien, an American, a Jew" (1998, p. 4), 6 months later his return for a high-school reunion sums up the ambiguities and contradictions which defined those moments. Though his reception is "outlandishly generous" (1998, p. 5), he (again) feels excluded and his opinions marginal; the drinking songs during a high school reunion party turned into nationalistic anthems "directed against foreigners, of which clearly I was one-though forgiven for the moment-and against émigrés, and I was forgiven for that, too" (1991, p. 234). The depiction of his 1997 return might resemble Nabokov's fictional scenarios of homecoming-only with a happy ending-for a reader not acquainted with the inner springs of a post-communist society. Because after 1996 Romania had turned officially to the West and made massive efforts to secure entrance into NATO, the government treated Codrescu, "the prodigal son, like returning royalty" (1998, p. 7), welcoming and honoring his work and activity in exile. His reception is so solemn and his work so celebrated in public speeches, that his penetrating eye cannot help underlining with overt ironic undertones that he "began fantasising that Romania might be [his] backdoor to the Nobel prize in literature" (1998, p. 9).

to his definition of exile; only once does he mention in passing their early anti-Semitic political affiliations. See "Return to Romania: Notes of a Prodigal Son" (1998) where he mentions them with an implicit critique of the present cultural elite, not a critique per se addressed to his exile icons. 
These successive meanings his exile condition undergoes, the everchanging welcomes eloquently indicate the early post-1989 governments' uneasy relationships in relation to the communist past and with the Romanian diaspora in general. In 2006, upon receiving the highly prestigious literary prize "Ovidius", Codrescu refers to himself as a "fortunate and reversed Ovid". ${ }^{17}$ His new self-definition is predicated once again on exile, the poetic implications and the fortunate historical, political moments which enabled his returns.

In telling his story of exile and returns he engages both culturally and journalistically with his native country in the aftermath of Communism, becoming her chronicler in multiple genres and media. The Romania of his autobiographical project is by turns a Romania of the mind, a fantasy world, depicted endearingly, the absurd world of the post-communist 1990s caught in multiple transitions-and thus the post/communist exotic he has a penchant for presenting to the American public-as well as the country he feels proud to belong to as his 2006 acceptance speech demonstrates.

Codrescu's life writing project illustrates an exilic trajectory which embodies a modernist understanding of exile, recoded within the communist context, which gave way to a transatlantic shuttling in the postCold War period. A "happy foreigner", Codrescu decidedly makes out of his exile condition, displaced identity, and a self caught between cultures and times the very dwelling he cherishes as a writer. The experience of exile, clearly grounded in the Romanian communist and post-communist context, is for him both the origin and the pool of resources that he does not only explore in his three autobiographies; the autobiographical detail is pieced out throughout his poetry, novels, essays, travelogues, NPR commentaries, ABC productions or magazine columns. ${ }^{18}$

His open ended, multi-genre autobiographical project inscribes itself in the American tradition of chronicling success and transformation while casting light on Eastern Europe, Romania in this case. In post-1989 life writing, the successful writer and popular NPR commentator clearly draws the trajectory of endless autobiographical representation in genres that morph themselves while capturing his Eastern European exilic identity.

\footnotetext{
17 "Andrei Codrescu s-a proclamat un Ovidiu pe dos" http://www.artline.ro/AndreiCodrescu-s-a-proclamat-un-Ovidiu-pe-dos-8535-1-n.html. The reference is to the Roman poet, Ovid, well known in Romania as he was banished by the emperor to Tomis on the Black Sea.

${ }^{18}$ Besides this three autobiographies [The Life and Times (1975), In American Shoes (1983), The Hole (1991)], Codrescu's work includes travelogues (The Road Scholar, Ay Cuba!), numerous autobiographical collections of essays (The Muse is Always Half Dressed in New Orleans, Zombification: Stories from the NPR) and poetry volumes.
} 


\section{KAPKA KASSABOVA'S BULGARIAN POST-COMMUNIST MISADVENTURES}

Post-1989 exilic trajectories, namely emigration after the fall of the Berlin Wall, are numerous given the staggering figures in many Eastern European national contexts but literary representations are still scarce. In making reference to Kapka Kassabova's memoir-travelogue, Street without a Name: Childhood and other Misadventures in Bulgaria (2008), I follow her exilic trajectory in the aftermath of the Cold War in order to highlight how the post-communist context can mark in intricate ways one's identity and one's belonging to her native country. ${ }^{19}$

The global itinerary of the celebrated poet, travel and fiction writer ${ }^{20}$ starts not under Communism, but in its aftermath; her family did not flee the Bulgarian totalitarian regime, the camps of the 1950 s, or the numerous forms of oppressions and deprivations the following decades imposed, but rather the democratic changes of the 1990s. Kassabova's trajectory is that of a "global soul" (2009, p. 7), she emigrated to New Zealand in 1992, lived or spent extensive lengths of time in France, Germany, Argentina, India, lives in the UK, goes to Bulgaria often. Consequently, the representations of exilic identity speak of and for the generation of Eastern Europeans who were brought up under Communism, experienced the post-communist transitions - the "winds of change" (p. 98) - and witnessed both from near and afar the long-desired process of "return to normalcy" and the convoluted and delayed European Union integration.

In the first part of the book, "Childhood", the inner exile and alienation characteristic of the communist period in Bulgaria of the late 1970s and $1980 \mathrm{~s}$ is presented poignantly but it also caters for the expectations of an international audience about the great Eastern European grayness and nothingness. She depicts how there was nothing to watch on TV, there wasn't much to eat, nothing to play with, just rusty playgrounds, a few green spaces and dirt (p. 29).

She portrays the inner exile one experienced and describes how the young girl found refuge in reading and learning foreign languages. Books offered "an inner world [...] an inhabitable space" (p. 43) and learning French meant the promise of a "ferry passage across the Styx" (p. 104).

\footnotetext{
${ }^{19}$ Linke (2013) in the present cluster discusses Kassabova's memoir as the "extraordinary ordinary" life under Communism and reads her exilic identity through the prism of nomadism, while Duppé interprets her memoir as a lieu de memoire and connects it to a larger discussion of Bulgarian identity.

${ }^{20}$ Her work includes the novels Reconnaissance-which won the Commonwealth best first novel award for Asia-Pacific_Love in the Land of Midas, Villa Pacifica and four volumes of poetry. Her second memoir Twelve Minutes of Love came out in 2012.
} 
The sense of the absurd and deprivation characterizing communist Bulgaria is presented through the eyes of the mature narrator, reflecting on her childhood or adolescence experience with anthropological precision. The autobiographer emphatically points how "escapist books" and the "company of other educated people" (pp. 53, 43) implied tacit resistance and even rebellion as these were the "only" acts of freedom left to the citizens "[o] therwise you were stuck with the mud, the psychopath downstairs, and the bear clan above" (p. 43). Others' views she includes give further vividness to her description. Her parents' insistence on learning offers a fuller picture of the despair and general alienation which characterized those living under Stalinist ideology: they offered endless threats to the young girl barely nine-unless she became a top student she'd "end up washing dishes in some dismal kitchen, married to a truck driver" who would beat her (p. 43).

The inner exile, multiple forms of alienation caused by the communist regime of 1980s Bulgaria, and the hopes of crossing the Styx enabled by learning French are brought in dialogue with similar experiences in the immediate aftermath of 1989. The fall of Communism brings "democracy and not much else, even the last of electricity was gone" (p. 129). The autobiographer poignantly portrays how six months later the newly embraced capitalism turned the socialist streets without names ${ }^{21}$ from the "wild East into the Wild West and it was hard to say which was worse [...] Yesterday's bully was today's entrepreneur" (p. 131). The sense of disillusionment and lack of hope lead to her family's emigration and her desperate desire to leave this world behind: "I don't know where I am going, but I don't want to come back" (p. 137). The final section of the autobiographical narration in "Childhood" clearly shows new forms of existential anguish and unsettledness that the post-1989 period brought about. If during Communism material hardships, economic deprivations and political, ideological oppression led to inner exile and alienation, a different form of the absurd, the abnormal is triggered by the transition period as Kassabova well depicts in describing the immediate aftermath of 1989 and her family's decision to emigrate.

The memoir does not record her stay in New Zealand, or her life experience elsewhere in the meantime, but her returns to Bulgaria in the early 2000s as a travel guide writer. In the second part of the book, "Other Misadventures", the autobiographical narrative merges into travelogue writing, and Kassabova depicts a Bulgaria in flux, coming to terms with market economy, democracy and the troubled legacy of the

${ }^{21}$ The title refers to the nameless streets which make up the massive estates in which she lived called Youth 1-3. 
past. The travelogue part brings into dialogue her communist experience, the post-communist one of the early 1990s with the visits in the 2000s when Bulgaria was becoming a new member of the enlarged European Union.

The masterful juxtaposition of the three historical periods she experienced that her travelogue renders-Communism, post-communism and the EU enlargement-parallels the similar complex subject positions she undergoes upon her returns. She takes turns in being a native, a tourist, a foreigner, a foreign journalist, the returned exile, just to discover the pitfalls and impossibility of any such identity. She feels like "a ghost from the past", (p. 292) when visiting Balcic, the seaside holiday of her childhood, or discovers how wrong she was to think about being just a "tourist" in places she never visited before (p. 303). The perspectives of the people she encounters and talks to-the Gastarbeiter, the duped naïve village girl fooled into emigration just to be sold as sexual commodity, the "damaged, self-obsessed, provincial hardened Mrs. Middle Bulgaria" (p. 317), the EU enthusiasts and the nationalistic peasant, the "Westerners" for whom Bulgaria is a "romantic" country, the real estate investors who mushroomed in the country buying cheap land on the Black Sea coast-become all pretexts for exploration not only of her country but also of herself, her contradictory forms of belonging to Bulgaria. The instance of her talking to a German businessman is a relevant case: "And what exactly am I doing now-apologizing to the foreigner as a Bulgarian, or complaining under the false guise of a foreigner? How tiring this process of self-consciousness" (p. 305). The conversations with her high school friends speak for her own struggles in understanding and coming to terms with identity, or her former colleagues even become alter egos as Rado's remark makes evident: "I can only be Bulgarian when I'm in France. Here, I am semi-French. Everything is funny and bizarre, and I laugh like someone watching a Beckett play" (p. 189).

The communist home she desperately wanted to escape becomes on her return in the early 2000s a psychic home. The home of her past becomes reconfigured by the exile's nostalgic yearning for her childhood world as the comments on listening to Ala Pugacheva's 1980s hits make clear: "We are singing an ironic but secretly nostalgic serenade to our communal lost youth of red armies, red scarves, red boots, red flags and red roses" (p. 291). There is no reconciliation however, but a continuous exploration of belonging complicated by the fact that contemporary post-communist Bulgaria is the world she feels even more alienated from. It is a world of promiscuous TV ads and absurd radio shows [about relationships, pimps, and orgasms] and she has to turn once again "to the bookshelves for therapy" (p. 14). Coming home during the first decade 
of 2000 seems sometimes like a remedy for any homesickness, it makes her sick of home "I don't know what is it...but I have an urge to go and never come back" (pp. 329-330). Despite the hopeful ending which focuses on the "brand new [airport] terminal" whose "halls gleam and sparkle...like something out of the The Matrix" (p. 335) and the "polite clerk" who smiles when handing her the passport, the book speaks about despair and disillusionment, it is an indictment of the present she tries to come to terms with.

This second part of the book is a continuous exploration of the postcommunist exilic identity, the tightly knitted social, economic and historical forces which inform it. The post-communist exilic identity analyzed and interrogated at length here can be seen as representative for Kassabova's generation in the former Eastern European communist bloc.

Gabrielle Linke associates the somewhat fragmented, hybrid and discontinuous autobiographical writing that Street without a Name puts forth with a "nomadic mode" though not in the joyful discontinuity Braidotti discusses nomadism (p. 12). Her detailed analysis of Kassabova's book insightfully points to the Eastern European "inferiority complex", connects the autobiographer's attempt of sharing her communist past to an international audience with Zygmunt Bauman's notion of "liquid modernity" (p. 15) and interprets her displaced identity as an "accomplished" flexible citizenship (p. 14). While Kassabova's global itinerary and literary success definitely illustrate the view Linke puts forth, the emphasis on the latently postcolonial, nomadic features or Ong's "flexible citizenship" with reference to autobiographical narrative tends to level out the specificities of the post-communist context. Linke's interpretative lenses and concepts grounded in other (rather dissimilar) experiences with currency in contemporary discourse enrich the analysis of Kassabova's memoir through their comparative component but they can also obliterate the emergence of interpretative frames deriving from the very text one discusses. It's the "unsettled Eastern European" Linke mentions (p. 12), in the aftermath of Communism, who explores herself and her native country that singles out Street without a Name, rather than the postcolonial and post-national intimations the autobiographer shares. Kassabova's memoir is a continuous reflection and interrogation of the post-communist cultural and personal identity, it is a continuous discussion of what belonging is and what it means to belong, to leave home and come home, what home is in postcommunist Bulgaria; it speaks about the impossibility of coming home, of belonging in the post-communist world.

Framed by her willed uprootedness but unwilling defamilarization, Kassabova creates a language of communist and post-communist alienation, geographical and ontological displacement which resonates well beyond 
her own experience. ${ }^{22}$ The exilic trajectory depicted in Kassabova's memoir becomes emblematic for the new global, transnational Eastern European generation, "the top export of socialism: several passports, foreign spouses, dynamic careers, borrowed identities. And fractured psyches" (p. 332), whose memories and stories are yet to be written. Her post-1989 life writing trajectory, rather conservative in form (childhood autobiography and travelogue), opens the way for further explorations of the post-communist experience in autobiographical form by Eastern Europeans.

\section{EASTERN EUROPEAN BELONGINGS}

The forms of exile that Suleiman, Codrescu and Kassabova put forth in their life writing articulate the multilayered pasts and the ever changing realities of the present in the former Eastern European bloc. They all share a socio-historical intimacy as history and political regimes impinged on individual destinies in striking ways. The multiple trajectories of exile their life writing presents parallel the multi-layered pasts of 20th century Eastern Europe, the "heavy weight of history" (Dickstein 2008, p. 129), or the "burden of history" (Hoffman, "Life" 2000, p. 15) that invariably characterized the destinies of numerous Eastern Europeans, whose "lives have been knocked around by history and dislocated by culture and geography" (Dickstein 2008, p. 129). However these "contested pasts" (to paraphrase Radstone Hodgkin 2003), the numerous historical "caesuras with different meanings" (Schlögel 2008) that took place in the aftermath of World War I and "impinged on people's lives in pressing and immediate ways" (Hoffman, "Life" 2000, p. 11), ${ }^{23}$ are far from having been explored in all their complexity and broad range of effects on people's lives within or outside national contexts.

By witnessing major changes from afar or near, by shuttling back and forth, the autobiographers discussed resignify personal and collective histories outside the immediate national locale. Suleiman, Codrescu and Kassabova record the shifting registers of their own identity, the changing realities (and imaginaries) of their home countries and rethink them

\footnotetext{
${ }^{22}$ Both the reactions to her book on amazon as well as her own analysis of the book's reception in Bulgaria and among the Bulgarian émigrés point to this, see Kassabova (2010).

${ }^{23}$ As Schlögel suggests whatever date one takes, different experiences are tied to it: "We need only think of 1918, 1937, 1938, 1939, 1941 or 1945. And in the post-war period: how differently the dates 1948, 1953, 1956, 1961, 1968, 1981 or even 1989 are remembered. A particular experience and perspective is linked to each date". For a similar approach and an in-depth analysis of memory in communist societies see also Tony Judt "The Past is Another Country" (1992, p. 172).
} 
in nuanced interpretative frames; they analyze both their identities and their countries incorporating them within larger frameworks, which their travels and professions enabled. In so doing, they bring the Eastern European space of their origin within a larger transatlantic, global matrix their identities are part of. Their forms of exile that my analysis reveals are isomorphic with the changes their countries underwent in the past sixty years and are also imbricated with their own individual destinies.

Their "soil of significance" (Hoffman, Lost p. 278), however, is always the specific Eastern European space and the practices they left behind, to which they relate critically. Their life writing furthers the understanding of migrations and displacements from behind the Iron Curtain, and the aftermath of its fall, although, as Ugrešić rightly points out, writers are statistically the most insignificant and unreliable witnesses. However, they are those "rare migrants who leave their footprints" (p. 127) and Suleiman, Codrescu and Kassabova leave precious footprints about exile from Eastern Europe during and in the aftermath of Communism. The trajectories their life writing enacts complete and enter in dialogue with the numerous life stories published at an increasing rate in most Eastern European countries in the last twenty years but which are less known and rarely circulated outside the national context.

\section{ACKNOWLEDGEMENTS}

The article is the result of a research project supported by Taiwan's National Science Council grant 100-2410-H-003 -138. I would like to thank the Timothy Ashplant, Leena Kurvet-Käosaar, Gabrielle Linke, and Christian Moser for their insightful comments and suggestions.

\section{REFERENCES}

Armstrong, Isobel. "Undoing Amnesia: An Interview with Susan Rubin Suleiman.” Women: A Cultural Review 9.2 (1998): 165-77.

Boym, Svetlana. The Future of Nostalgia. New York: Basic Books, 2001.

Brodsky, Joseph. Less than One: Selected Essays. New York: Farrar, Straus \& Giroux, 1986.

Brodsky, Joseph. On Grief and Reason. New York: Farrar, Straus \& Giroux, 1995.

Codrescu, Andrei. The Life and Times of an Involuntary Genius. New York: George Braziller, 1975 .

Codrescu, Andrei. In America's Shoes. San Francisco: City Lights Books, 1983.

Codrescu, Andrei. The Disappearance of the Outside. Reading, MA: Addison Wesley, 1990.

Codrescu, Andrei. The Hole in the Flag: A Romanian Exile's Story of Return and Revolution. New York: William Morrow, 1991.

Codrescu, Andrei. "Return to Romania: Notes of a Prodigal Son." The Washington Quarterly 21.1 (1998): 3-20. 
Codrescu, Andrei. "How I Escaped Cold War Romania." Moment. December (2005): 84.

Davis, Rocío G. "Academic Autobiography and/in the Discourses of History." Rethinking History: The Journal of Theory and Practice. 13.1 (2009a): 1-4.

Davis, Rocío G. "Out of the University: Reading Academic Autobiographies." Prose Studies 31.3 (2009b): 159-65.

Dickstein, Morris, "Questions of Identity: The New World of the Immigrant Writer." The Writer Uprooted: Contemporary Jewish Exile Literature. Ed. Alvin H. Rosenfeld. Bloomington: Indiana University Press, 2008.

Duppé, Claudia. "Tourist in Her Native Country: Kapka Kassabova's Street Without a Name." Facing the East in the West: Images of Eastern Europe in British Literature, Film and Culture. Ed. Barbara Korte, Eva Ulrike Pirker, and Sissy Helff. Amsterdam: New York, NY: Rodopi, 2010.

Franklin, Cynthia G. Academic Lives: Memoir, Cultural Theory, and the University Today. Athens: University of Georgia Press, 2009.

George, Rosemary Marangoly. The Politics of Home: Postcolonial Relocation and Twentieth Century Fiction. New York: Cambridge University Press, 1996.

Goldsworthy, Vesna. Inventing Ruritania: The Imperialism of the Imagination. New Haven: Yale University Press, 1998.

Hammond, Andrew. "The Danger Zone of Europe: Balkanism between the Cold War and 9/11." European Journal of Cultural Studies. 8.2 (2005): 135-154.

Hirsch, Marianne. Family Frames: Photography, Narrative, and Postmemory. Cambridge, MA: Harvard University Press, 1997.

Hirsch, Marianne. "Surviving Images: Holocaust Photographs and the Work of Postmemory." Yale Journal of Criticism 14.1 (2001): 5-38.

Hirsch, Marianne, and Leo Spitzer. Ghosts of Home: The Afterlife of Czernowitz in Jewish Memory. Berkeley, Los Angeles: University of California Press, 2010.

Hirsch, Marianne, and Nancy K. Miller, eds. Rites of Return: Diaspora Poetics and the Politics of Memory. New York: Columbia University Press, 2011.

Hirsch, Marianne. The Generation of Postmemory: Writing and Visual Culture After the Holocaust. New York: Columbia University Press, 2012.

Hoffman, Eva. Lost in Translation. New York: Penguin Books, 1990.

Hoffman, Eva. "The New Nomads." Letters of Transit. Reflections on Exile, Identity, Language and Loss. Ed. Andre Anciman. New York: New Press in collaboration with New York Public Library, 1999. 41-63.

Hoffman, Eva. "Complex Histories, Contested Memories: Some Reflections and Remembering Difficult Pasts." Occasional Papers of the Doreen T Townsend Center for Humanities 23. Berkeley: University of California, 2000.

Hoffman, Eva. "Life Stories, East and West." The Yale Review 88.1 (2000): 1-19.

Hornung, Alfred. "Return Visits: The European Background of Transcultural Life Writing." European Journal of Life Writing. Vol. 2 (2013).

Ioanid, Radu. The Ransom of the Jews: The Story of the Extraordinary Secret Bargain between Romania and Israel. Chicago: Ivan R. Dee, 2005.

Judt, Tony. "The Past is Another Country: Myth and Memory in Postwar Europe." Daedalus 4 (1992): 83-118.

Kassabova, Kapka. Street without a Name: Childhood and Other Misadventures in Bulgaria. New York: Skyhorse Pub., 2009.

Kassabova, Kapka. "From Bulgaria with Love and Hate: The Anxiety of the Distorting Mirror." Facing the East in the West: Images of Eastern Europe in British Literature, Film and Culture. Ed. Barbara Korte, Eva Ulrike Pirker, and Sissy Helff. Amsterdam; New York, NY: Rodopi, 2010. 67-78. 
Kristeva, Julia. Strangers to Ourselves. New York: Columbia University Press, 1991.

Kristeva, Julia. "Y at-il des étrangers heureux?" Migrations et errances. Ed. Françoise BarretDucrocq, Paris, Grasset, 2000.

Kundera, Milan. Ignorance. Trans. Linda Asher. New York: HarperCollins, 2002 (1999).

Linke, Gabrielle. "Belonging in Post-communist Europe: Strategies of Representation in Kapka Kassabova's Street without a Name." European Journal of Life Writing. Vol. 2 (2013).

Manea, Norman. "Happy Guilt: Mircea Eliade, Fascism, and the Unhappy Fate of Romania." The New Republic August, 1991. 35-37.

McDonald, Christie, and Susan Rubin Suleiman, eds. French Global: A New Approach to Literary History. New York: Columbia University Press, 2010.

Miller, Nancy K. What They Saved: Pieces of a Jewish Past. Lincoln: University of Nebraska Press, 2011.

Neubauer, John et al., eds. The Exile and Return of Writers from East-Central Europe: A Compendium. Berlin: Walter de Gruyter, 2009.

Polouektova, Ksemia. “'Is There a Place like Home?’ Jewish Narratives of Exile nad Homecoming in Late Twentieth century East Central Europe." The Exile and Return of Writers from East-Central Europe: A Compendium. Eds. John Neubauer, et al. Berlin, 2009. 432-469.

Radstone, Susannah and Hodgkin, Katherine, eds. Contested Pasts: The Politics of Memory. London: Routledge, 2003.

Rădulescu, Domnica, ed. Realms of Exile: Nomadism, Diasporas, and Eastern European Voices. Lanham, Md.: Lexington Books. Rowman \& Littlefield, 2002.

Schlögel, Karl. "Places and Strata of Memory, Approaches to Eastern Europe." Eurozine. 2008. 12. 19. <http:/ /www.eurozine.com/articles/2008-12-19-schlogel-en.html>

Said, Edward. The World, the Text and the Critic. New York: Vintage, 1991.

Sebastian, Mihail. Journal 1935-1944: The Fascist Years. Trans. Patrick Camiller. Chicago: Ivan R. Dee, 2000 (1996).

Segel, Harold B. The Columbia Literary History of Eastern Europe Since 1945. New York: Columbia University Press, 2008.

Smith, Sidonie, and Julia Watson, eds. Reading Autobiography: A Guide for Interpreting Life Narratives. Minneapolis: University of Minnesota Press, 2010.

Smith, Sidonie. "Presidential Address 2011: Narrating Lives and Contemporary Imaginaries." PMLA 126. 3 (2011): 564-575.

Spiridon, Monica. "La Vest de Eden." ("West of Eden") Secolul XX. 10-12/ 1997-1-3/1998, 224-234.

Suleiman, Susan Rubin. Authoritarian Fictions: The Ideological Novel as a Literary Genre. New Jersey: Princeton University Press, 1983.

Suleiman, Susan Rubin, ed. The Female Body in Western Culture: Contemporary Perspectives. Cambridge: Harvard University Press, 1986.

Suleiman, Susan Rubin. Subversive Intent: Gender, Politics, and the Avant-Garde. Cambridge: Harvard University Press, 1990.

Suleiman, Susan Rubin. Risking Who One Is: Encounters With Contemporary Art and Literature. Cambridge: Harvard University Press, 1994.

Suleiman, Susan Rubin. Budapest Diary. In Search of Motherhood. Lincoln \& London: University of Nebraska Press, 1996.

Suleiman, Susan Rubin. "Monuments in a Foreign Tongue: On Reading Holocaust Memoirs by Immigrants." Exile and Creativity, Signposts, Travelers, Outsiders, and Backward Glances. Ed. Susan Rubin Suleiman. Durham, NC: Duke University Press, 1998. 397-418.

Suleiman, Susan Rubin, ed. Exile and Creativity, Signposts, Travelers and Outsiders Backward Glances. Durham, NC: Duke University Press, 1998.

Suleiman, Susan Rubin, and Eva Forgacs, eds. Contemporary Jewish Writing in Hungary: An 
Anthology. Lincoln and London: University of Nebraska Press, 2003.

Suleiman, Susan Rubin. Crises of Memory and the Second World War. Cambridge: Harvard University Press, 2006.

Suleiman, Susan Rubin "Writing and Internal Exile in Eastern Europe: The Example of Imre Kertèsz." The Exile and Return of Writers from East-Central Europe: A Compendium. Eds. John Neubauer, et al. Berlin, 2009. 432-469.

Suleiman, Susan Rubin, Phelan James, and Lothe Jakob, eds. After Testimony: Holocaust Literature Today. Columbus: Ohio University Press, 2012.

Talbot, Stephen. "Romania: My Old Haunts. Interview with Andrei Codrescu." October 2002. $<$ <ww.pbs.org/frontlineworld/stories/romania/interview.html>.

Todorova, Maria. Imagining the Balkans. New York: Oxford University Press, 1997.

Ugrešić, Dubravka. "The Writer in Exile." Thank You for Not Reading: Essays on Literary Trivia. Trans. Celia. Hawkesworth. Normal, IL: Dalkey Archive Press, 2003. 127-149.

Wolff, Larry. Inventing Eastern Europe: The Map of Civilization on the Mind of the Enlightenment. Stanford: Stanford University Press, 1994.

\section{BIOGRAPHICAL NOTE}

Ioana Luca is Assistant Professor at National Taiwan Normal University, where her research focuses on American literature, post-1989 Eastern European life writing, as well as American Studies in global contexts. She has published articles in Social Text, Rethinking History, Prose Studies, Biography: An Interdisciplinary Quarterly, chapters in edited volumes, and several translations in and from Romanian. She is the principal investigator of the NSC-funded project Discourses of Memory in Eastern European Exiles' Life Writing and is completing a book on autobiography and exile in post-1945 American literature. 